\title{
Effect of two wild rootstocks of genus Passiflora L. on the content of antioxidants and fruit quality of yellow passion fruit
}

\author{
Alejandro Hurtado Salazar*, Danielle Fabíola Pereira da Silva, Claudio Horst Bruckner \\ Universidade Federal de Viçosa - Departamento de Fitotecnia - Viçosa (MG), Brasil.
}

\begin{abstract}
The nutritional importance of the fruit of passionfruit has prompted studies to assess its composition and antioxidant content and to evaluate it as a functional food in fresh fruit and concentrated juice markets. Currently, the use of wild species as rootstock has been recommended mainly for their positive effects such as tolerance to disease attack and maintenance of fruit quality of grafted cultivars. The aim of this study was to determine the effect of wild species of Passiflora gibertii N.E. Br. and Passiflora mucronata Lam as rootstock on the content of antioxidants and fruit quality of Passiflora edulis $\mathrm{f}$. flavicarpa. The experimental design was completely randomized with four treatments and 25 replications, with a total of 100 experimental units. As a control treatment, plants of $P$. edulis from seed and grafted
\end{abstract}

\section{INTRODUCTION}

The genus Passiflora is composed of about 530 species, 60 of which produce edible fruits (Ocampo et al. 2007) and few of these are cultivated. The market for fresh passion fruit is valued for desirable internal and external quality features of the fruit - the internal quality features are those related to taste (soluble solids and acidity) and juice content (yield), and the external ones are those related to good appearance (color of the skin, size, weight and absence of defects) - thus, meeting certain standards to achieve the desired quality in the markets (Ocampo et al. 2013).

A predominant feature is the presence of antioxidants in the fruits and in the substrates from the leaves of some species of Passiflora, according to Pabón et al. (2011), who found significant values for fruits of wild granadilla (P. ligularis Juss) and gulupa (P. edulis f. edulis Sims) leaves. on the same species were used. Significant correlations were observed among the contents of $\beta$-carotene, ascorbic acid, luminosity values, chroma and hue angle. For the combination $P$. edulis/P. gibertti, the contents of $\beta$-carotene and ascorbic acid were highly correlated with luminosity, chroma and hue angle of fruit juice. A similar behavior was observed for the combination P. edulis/P. mucronata Lam. The content of $\beta$-carotene in the fruit showed no statistical differences $(p<0.05)$, indicating no significant rootstock effect on the variables evaluated. The results indicate a potential wild rootstock use for its positive effects on grafted plants while maintaining the commercial quality of the fruits of passionfruit crops.

Key words: Passifloraceae, $\beta$-carotene, vitamin $C$, rootstock. 
(Babbar et al. 2011). As responsible for being the precursor of vitamin $A$, essential for vision, $\beta$-carotene plays a key role in human health (Rotili et al. 2013). Other beneficial effects of carotenoids include anti-cancer and heart disease prevention properties, which has stimulated intensive research on the role of these compounds as antioxidants and as regulators of the immune system response.

Grafting is widely used in fruit-culture and in other perennial species to propagate superior genotypes, to control plant size, reduce juvenile period, improve the adaptation to adverse soil conditions and to provide tolerance to pests and diseases (Atucha et al. 2014; Machado et al. 2013; Salazar et al. 2015).

In Passiflora crops, tolerance of some wild species such as Passiflora suberosa L., P. alata Curtis, P. coccinea Aubl., P. setacea D.C. and P. gibertii N.E.Br. to premature death of the plants (Fusarium spp.) was reported by Silva et al. (2013). Thus, there have been several studies, as those reported by Cavichioli et al. (2011) and Salazar et al. (2015), evaluating the effect of rootstock and graft type on fruit quality of yellow passionfruit, finding that the rootstocks (P. edulis, P. alata, P. mucronata and P. gibertii) did not influence the content of soluble solids (SS), titratable acidity (TA) and the SS/TA ratios. Similarly, the grafting method did not affect the diameter, length, weight of the fresh fruit, weight and thickness of the rind, and juice yield. However, little information is available on the effect of wild species of Passiflora as rootstock for cultivation of passionfruit and their influence on the antioxidant properties of the fruit. Thus, the aim of this study was to determine the effect of two wild species as rootstocks on the content of antioxidants and fruit quality of yellow passion fruit.

\section{MATERIAL AND METHODS Study area}

The study was conducted in a protected environment with a low-density polyethylene covering with a thickness of $150 \mu \mathrm{m}$ and side anti-aphid greenhouse mesh for citrus fruit in the fruit-culture sector of the Universidade Federal de Viçosa (UFV), Viçosa (MG), Brazil. Geographically, the experimental area is located at a latitude of $20^{\circ} 45^{\prime} 20^{\prime \prime}$ south and a longitude of $42^{\circ} 52^{\prime} 40^{\prime \prime}$ west, with an altitude of 650 m.a.s.l., with an average annual temperature of $19^{\circ} \mathrm{C}$. According to Köppen's classification, the weather is Cwa-type, mesothermal, with rainy summers and cold, dry winters (Matarazzo et al. 2013).

\section{Plant material}

The experimental design was completely randomized with four treatments and 25 replications, totaling 100 plots. Each plot was represented by a plant in a pot of 30L. The rootstocks evaluated were: Passiflora edulis f. flavicarpa, Passiflora gibertii and Passiflora mucronata.; P. edulis plants from seed and grafted on the same species were used as a control treatment.

\section{Methodology}

For the production of plants used as rootstock, the seeds of P. edulis, P. mucronata and P. gibertii were obtained from the Passiflora collection of the fruit-culture sector of the UFV, as well as the vegetative buds used for grafting. The production of seedlings in the nursery began with seed germination in washed sand in plastic boxes of $40 \mathrm{~cm}$ of width $\times 20 \mathrm{~cm}$ of height $\times 50 \mathrm{~cm}$ of length. After complete expansion of cotyledonary leaves, 150 seedlings of each species were transplanted to plastic bags of $10 \mathrm{~cm} \times 23 \mathrm{~cm}$. At 60 days after planting, central-slit-type grafting at $10 \mathrm{~cm}$ from the root collar of the plant was conducted. Vegetative buds, with two knots, were removed from the middle portion of the productive branches of five adult yellow passionfruit plants. With the first shoots of the graft, the plants were transplanted at four months of age to pots of $30 \mathrm{~L}$ in a greenhouse.

The substrate was formed by a mixture of soil, sand and chicken manure in a ratio of 3:1:1 by volume. Each pot was supplemented with $100 \mathrm{~g}$ of calcium carbonate as corrective measure according to the soil analysis, 1,000 $\mathrm{g}$ of manure and $300 \mathrm{~g}$ of simple superphosphate. The plants were staked with plastic fiber attached to a 12-caliber steel wire located at an elevation of $2 \mathrm{~m}$. Pruning of side branches (deshooting) was performed every 15 days or according to the development of the plant.

When the plants reached $15 \mathrm{~cm}$ of height, 60 days after transplantation, the first fertilization was performed with $5 \mathrm{~g}$ of ammonium sulfate and $10 \mathrm{~g}$ of potassium chloride; after 30 days, a second fertilization was performed, providing $10 \mathrm{~g}$ of ammonium sulfate and $15 \mathrm{~g}$ of potassium chloride, for a total of $15 \mathrm{~g}$ of $\mathrm{N}$ and 20 of $\mathrm{P}_{2} \mathrm{O}_{5}$, considering that ammonium sulphate and potassium chloride contain approximately 
$20 \% \mathrm{~N}$ and $60 \% \mathrm{~K}_{2} \mathrm{O}$, respectively. Additionally, it was necessary to fertilize with $21 \mathrm{~g}$ of ammonium sulfate diluted in $1 \mathrm{~L}$ of water per plant and $13 \mathrm{~g}$ of agricultural gypsum beginning 60 days after transplantation, every 15 days for 250 days. It was also necessary to apply the acaricide abamectin (18 g of active ingredient per L) 60 days after transplantation. Cultural practices and plant management were performed in accordance with technical recommendations for the cultivation of passion fruit (Meletti 2011). A drip irrigation system was used, where each irrigation line had two drips with discharges of $1 \mathrm{~L} \cdot \mathrm{h}^{-1}$ arranged around each plant, which was irrigated daily.

\section{Chemical characterization}

To evaluate the antioxidant composition and quality of the fruit, 172 flowers on each plant were pollinated. Artificial pollination was done manually between 14 and $17 \mathrm{~h}$, when there were open flowers between August and December 2012, for an average of ten fruits per plant; thus, ten fruits per plot were evaluated for analysis.

To evaluate carotenoids, about $2.0 \mathrm{~g}$ of juice were weighed, which were homogenized in a beaker with $80 \%$ acetone. The ketone extract was filtered through filter paper $(8 \mu \mathrm{m})$, and the volume was completed to $25 \mathrm{~mL}$ in a tube (Silva et al. 2014). The absorbance was determined at $470,646.8$ and $663.2 \mathrm{~nm}$, and carotenoid levels were determined according to the Lichtenthaler equations (1987). The results were expressed in mg per $100 \mathrm{~g}$ of juice.

Total SS were determined with three drops of juice, after extraction, using a digital refractometer. TA was determined with the juice of each of the fruits, obtained by $5 \mathrm{~mL}$ of juice and transferred to an Erlenmeyer of $250 \mathrm{~mL}$, completing the volume to $100 \mathrm{~mL}$ with distilled water. Three drops of the indicator phenolphthalein at $1 \%$ were added to this solution, proceeding to stirring titration with $\mathrm{NaOH} 0.1 \mathrm{~N}$ solution, previously standardized with potassium hydrogen phthalate. The results were expressed in $\mathrm{g}$ of citric acid per $100 \mathrm{~g}$ of juice. The SS/TA ratio was obtained by the quotient between the two characteristics.

The ascorbic acid content was determined by titration with Tillman's reagent [2,6 dichlorophenolindophenol (sodium salt) $0.1 \%$ ]. The results were expressed in mg per $100 \mathrm{~L}$ of ascorbic acid per $100 \mathrm{~g}$ of sample.

The coloration of the juice and the rind of the fruit were analyzed with a MINOLTA CR-10, based on the values of $L, C(\mathrm{~b})$ and $h^{\circ}$, where $L$ indicates the luminosity $(0=$ black and $100=$ white), $C$ represents chroma, $h^{\circ}$ is the hue angle and $b$ represents the chromaticity coordinates $(+a=$ red, $-a=$ green, $+\mathrm{b}=$ yellow and $-\mathrm{b}=$ blue). These values were converted to color angle, $\lambda^{\circ}=\tan ^{-1} \mathrm{~b} / \mathrm{a}$, which indicates the hue angle of the sample $\left(0^{\circ}\right.$ or $360^{\circ}=$ red, $90^{\circ}=$ yellow, $180^{\circ}=$ green, and $270^{\circ}=$ blue) (Silva et al. 2014). To determine the coloring of the rind, two readings were taken on opposite sides of each fruit. To define the color of the juice, it was extracted previously and poured into a beaker of $100 \mathrm{~mL}$, where the reading was done with the apparatus at $1 \mathrm{~cm}$ from the surface of the juice.

\section{Data analysis}

The data were evaluated by analysis of variance using SAS statistical software (SAS Institute 2002); then, evidence of comparative averages was performed by the Duncan's test at a level of significance of 5\%, and a Pearson's linear correlation between variables was performed.

\section{RESULTS AND DISCUSSION}

The antioxidant composition of passionfruit juice was evaluated by the content of $\beta$-carotene and ascorbic acid. These compounds were quantified in the fractions of juice and are related to its antioxidant biochemical mechanism (Pérez-Jiménez et al. 2008). The $\beta$-carotene content of passionfruit juice was not significantly changed by the different combinations of rootstocks (Table 1). It is noticeable that, despite the passionfruit plants' suffering due to a cut by the grafting (wound) and cicatrization processes as described by Salazar et al. (2015), as well as oxidative reactions of

Table 1. Characterization of antioxidant ( $\beta$-carotene and ascorbic acid) and chemical content in fruits of passionfruit plants (Passiflora edulis Sims) grafted on P. edulis Sims, P. gibertti, P. mucronata and non-grafted (by seed), in Viçosa (MG).

\begin{tabular}{|ccc|}
\hline Species & $\beta$-carotene* & Ascorbic acid $^{*+}$ \\
\hline P. edulis/P. gibertti & $1.0490 \mathrm{a}$ & $29.37 \mathrm{c}$ \\
\hline P. edulis/P. mucronata & $1.3362 \mathrm{a}$ & $30.93 \mathrm{~b}$ \\
\hline P. edulis/P.edulis & $1.4537 \mathrm{a}$ & $29.64 \mathrm{bc}$ \\
\hline P. edulis (non-grafted) & $1.0585 \mathrm{a}$ & $36.06 \mathrm{a}$ \\
\hline CV (\%) & $\mathbf{3 1 . 5 9}$ & $\mathbf{2 3 . 6 2}$ \\
\hline SD & $\mathbf{0 . 3 3}$ & $\mathbf{3 . 4 4}$ \\
\hline
\end{tabular}

*Values followed by different letters differ significantly $(p<0.05)$ according to Duncan's test. ${ }^{+}$Taken and complemented from the work of Salazar et al. (2015). $\mathrm{CV}=$ Coefficient of variation; $\mathrm{SD}=$ Standard deviation . 
maturation metabolism in early stages, there was retention of $\beta$-carotene in the juice. Regarding the levels of $\beta$-carotene, the fruits analyzed in this study were compared, as a reference, to carrots, which are known by presenting concentrations of this carotenoid. Campos et al. (2006) concluded that, out of the seven vegetables studied, carrots had the highest levels of $\beta$-carotene, with an average of $5.18 \mathrm{mg}$.

According to Table 1, the contents of ascorbic acid found in the fruit of $P$. edulis with all combinations of rootstocks and P. edulis Sims (without grafting) exceed the value of $20 \mathrm{mg}$ of ascorbic acid per $100 \mathrm{~g}$ of juice. The highest values of ascorbic acid were found in non-grafted P. edulis, followed by P. edulis/P. mucronata (36.06 versus $29.37 \mathrm{mg} 100 \mathrm{~g}$ of juice, respectively; $\mathrm{p} \leq 0.05$ ) (Table 1 ). In contrast, the combinations P. edulis/P. gibertti and P. edulis/P. edulis showed the lowest values of ascorbic acid (29.37 and $29.64 \mathrm{mg} 100 \mathrm{~g}$ of juice). These results are promising because all combinations had more than $20 \mathrm{mg}$ per $100 \mathrm{~g}$ of juice, the minimum market value required for passion fruit (Santos et al. 2009). In general, these results suggest that phytogenetic resources can be utilized as rootstock without a negative effect on fruit market quality. The content values of ascorbic acid ranged from 29.37 to 36.06, denoting a higher content in P. edulis (not grafted), followed by the combination P. edulis/P. edulis (autograft) and with the lower contents of rootstock in combinations of wild species (P. gibertti and P. mucronata). Souza et al. (2012) evaluated the chemical composition, bioactive compounds and the present antioxidant activity in the pulp of five types of fruits of Brazilian Cerrado, including the species Passiflora alata Dryand, which showed $\beta$-carotene content from $1.31 \pm 0.03 \mathrm{mg}$ per $100 \mathrm{~g}$ considered low by researchers, as well as ascorbic acid with $24.66 \pm 4.29 \mathrm{mg}$ per $100 \mathrm{~g}$ of juice. According to Ramful et al. (2011), fruits are classified according to the content of ascorbic acid in three categories: low (<30 mg per $100 \mathrm{~g}$ ), medium ( $30-50 \mathrm{mg}$ per $100 \mathrm{~g}$ ) and high (>50 mg per $100 \mathrm{~g}$ ). According to this classification, the fruits of the combination P. edulis/P. mucronota and P. edulis (ungrafted) qualify as with medium content and combinations P. edulis/P. gibertii and P. edulis/P. edulis are considered low.

Other authors such as Coelho et al. (2010) reported a decrease in ascorbic acid in the early stages of passionfruit ripening at $22^{\circ} \mathrm{C}$. These same authors reported ascorbic acid levels similar to those found in this study, varying from 25 to $30 \mathrm{mg}$ per $100 \mathrm{~mL}$. According to Lee and Kader (2000), the content of ascorbic acid in the fruit is strongly influenced by normal metabolism (maturation and senescence) and other types of post harvest stress. Thus, the levels of ascorbic acid in the organs of the plant are tightly controlled by the levels of synthesis, degradation, transport and recycling within the cell (Rotili et al. 2013). Due to the antioxidant properties of ascorbic acid, the route of recycling is particularly important in the fruit during the body's response to oxidative stress, when the reduced ascorbic acid is oxidized to the unstable form of dehydroascorbic acid, which can be easily degraded. Conforming with Stevens et al. (2008), the reduced form of ascorbic acid can die out if the oxidized forms are not recovered by reductase enzymes (monodehydroascorbate and dehydroascorbate reductase), genetically expressed in response to oxidative stress.

All the fruits of passionfruit in the different combinations of rootstocks studied in this work showed low concentrations of $\beta$-carotene compared to carrots; fruits from combinations P. edulis/P. edulis and P. edulis/P. mucronata showed the highest numerical levels of $\beta$-carotene with 1.45 and $1.34 \mathrm{mg}$ per $100 \mathrm{~g}$, respectively.

As reported by Uenojo et al. (2007), carotenoid levels in fruit cells remain relatively constant until the onset of senescence, and two types of enzymes are responsible for the oxygenation and degradation of carotenoids: lipoxygenase derived from chloroplasts, which catalyze the conversion of unsaturated lipids into aroma compounds; and peroxidase, from mitochondria. $\beta$-carotene retention in the juice of the fruits of grafted plants in wild Passiflora reveals the benefit of maintaining their nutritional bioavailability.

Significant correlations were observed among the contents of $\beta$-carotene, ascorbic acid and luminosity values $(L)$, chroma $(C)$ and hue angle $\left(h^{\circ}\right)$ (Table 2). For the combination P. edulis/ P. gibertti, the contents of $\beta$-carotene and ascorbic acid were highly correlated with luminosity, chroma and hue angle of fruit juice with values of $44.02,10.00$ and $94.45^{\circ}$, respectively, indicating that the juice of the fruits of this combination have a low amount of saturation or pigment, as well as a yellow color $\left(>90^{\circ}\right)$. A similar behavior was observed with the combination P. edulis/P. mucronata in the content of ascorbic acid and a highly significant correlation with the hue angle of juice with a value of $94.45^{\circ} ; L, C$ and $h^{\circ}$ of the rind of the fruits of this combination, with values of $70.93,43.15$ and $92.31^{\circ}$, respectively, indicate that the juice of the fruits has an intense yellow color $\left(>90^{\circ}\right)$, and the rind has a high saturation of pigments and an intense yellow color. In this same combination, the content of $\beta$-carotene was significantly correlated with the content of titratable acidity with values of $4.72 \mathrm{~g}$ per $100 \mathrm{~g}$ of citric acid. 
Table 2. Pearson's linear correlation coefficient between the chemical and physical variables of the fruits of passionfruit (Passiflora edulis Sims) grafted on P. edulis Sims, P. gibertii, P. mucronata and non-grafted (by seeds), in Viçosa (MG).

\begin{tabular}{|c|c|c|c|c|c|c|c|c|c|c|c|}
\hline Species & Variables & $\begin{array}{c}L \\
\text { (Juice) }\end{array}$ & $\begin{array}{c}\text { C } \\
\text { (Juice) }\end{array}$ & $\begin{array}{c}h^{\circ} \\
\text { (Juice) }\end{array}$ & $\stackrel{L}{\text { (Rind) }}$ & $\underset{\text { (Rind) }}{\text { C }}$ & $\begin{array}{c}\boldsymbol{h}^{\circ} \\
\text { (Rind) }\end{array}$ & $\begin{array}{c}\text { Relation } \\
\text { soluble } \\
\text { solids/acidity }\end{array}$ & $\begin{array}{l}\text { Soluble } \\
\text { solids }\end{array}$ & $\begin{array}{c}\text { Titratable } \\
\text { acidity }\end{array}$ & $\begin{array}{c}\text { Ascorbic } \\
\text { acid }\end{array}$ \\
\hline \multirow{10}{*}{$\begin{array}{l}\text { P. edulis/ } \\
\text { P. gibertti }\end{array}$} & $\beta$-carotene & $-0.43^{\star \star}$ & $-0.38^{\star \star}$ & $-0.12^{\mathrm{ns}}$ & $-0.12^{\mathrm{ns}}$ & $-0.02^{\mathrm{ns}}$ & $0.04^{\mathrm{ns}}$ & $-0.03^{n s}$ & $0.05^{\mathrm{ns}}$ & $0.10^{\text {ns }}$ & $-0.11^{\mathrm{ns}}$ \\
\hline & $\begin{array}{l}\text { Ascorbic } \\
\text { acid }\end{array}$ & $-0.11^{\text {ns }}$ & $-0.03^{\mathrm{ns}}$ & $0.40^{\star \star}$ & $-0.17^{\text {ns }}$ & $0.01^{\text {ns }}$ & $0.01^{\text {ns }}$ & $0.08^{\text {ns }}$ & $0.20^{\text {ns }}$ & $0.15^{\mathrm{ns}}$ & \\
\hline & $\begin{array}{c}\text { Titratable } \\
\text { acidity }\end{array}$ & $-0.01^{\mathrm{ns}}$ & $0.15^{\mathrm{ns}}$ & $0.23^{\text {ns }}$ & $0.30^{*}$ & $0.42^{\star \star}$ & $-0.39^{\star \star}$ & $-0.61^{\star \star}$ & $0.37^{\star \star}$ & & \\
\hline & $\begin{array}{l}\text { Soluble } \\
\text { solids }\end{array}$ & $0.25^{\mathrm{ns}}$ & $0.35^{\star}$ & $0.01^{\text {ns }}$ & $0.32^{\star}$ & $0.45^{\star \star}$ & $-0.36^{\star \star}$ & $0.49^{\star \star}$ & & & \\
\hline & $\begin{array}{l}\text { Relation } \\
\text { soluble } \\
\text { solids/ } \\
\text { acidity }\end{array}$ & $0.17^{\mathrm{ns}}$ & $0.13^{\text {ns }}$ & $-0.23^{n s}$ & $-0.03^{\text {ns }}$ & $0.01^{\text {ns }}$ & $0.04^{\mathrm{ns}}$ & & & & \\
\hline & $h^{\circ}$ (Rind) & $-0.12^{\mathrm{ns}}$ & $0.05^{\text {ns }}$ & $0.75^{\mathrm{ns}}$ & $-0.66^{\star \star}$ & $-0.84^{\star \star}$ & & & & & \\
\hline & $C$ (Rind) & $0.08^{\text {ns }}$ & $-0.08^{\mathrm{ns}}$ & $-0.01^{\mathrm{ns}}$ & $0.67^{\star \star}$ & & & & & & \\
\hline & $L$ (Rind) & $0.24^{\text {ns }}$ & $0.06^{\text {ns }}$ & $-0.08^{\text {ns }}$ & & & & & & & \\
\hline & $h^{\circ}$ (Juice) & $-0.18^{\mathrm{ns}}$ & $0.02^{\text {ns }}$ & & & & & & & & \\
\hline & $C$ (Juice) & $0.78^{\star \star}$ & & & & & & & & & \\
\hline \multirow{10}{*}{$\begin{array}{c}\text { P.edulis/ } \\
\text { P. mucronata }\end{array}$} & $\beta$-carotene & $0.06^{\text {ns }}$ & $-0.02^{\mathrm{ns}}$ & $-0.05^{\mathrm{ns}}$ & $-0.04^{\mathrm{ns}}$ & $0.08^{\text {ns }}$ & $-0.10^{\mathrm{ns}}$ & $-0.18^{\mathrm{ns}}$ & $0.068^{\mathrm{ns}}$ & $0.25^{\star}$ & $0.15^{\mathrm{ns}}$ \\
\hline & $\begin{array}{l}\text { Ascorbic } \\
\text { acid }\end{array}$ & $-0.16^{\mathrm{ns}}$ & $0.01^{\text {ns }}$ & $0.23^{\star}$ & $-0.35^{\star \star}$ & $-0.33^{\star \star}$ & $0.32^{\star \star}$ & $0.040^{\text {ns }}$ & $-0.026^{n s}$ & $-0.05^{\mathrm{ns}}$ & \\
\hline & $\begin{array}{c}\text { Titratable } \\
\text { acidity }\end{array}$ & $0.16^{\mathrm{ns}}$ & $0.08^{\text {ns }}$ & $-0.11^{\mathrm{ns}}$ & $0.36^{\star \star}$ & $0.32^{\star \star}$ & $-0.36^{\star \star}$ & $-0.87^{\star \star}$ & $0.16^{\text {ns }}$ & & \\
\hline & $\begin{array}{l}\text { Soluble } \\
\text { solids }\end{array}$ & $0.14^{\text {ns }}$ & $0.11^{\text {ns }}$ & $-0.09^{n s}$ & $0.27^{\star}$ & $0.31^{\star \star}$ & $-0.38^{\star \star}$ & $0.32^{\star \star}$ & & & \\
\hline & $\begin{array}{l}\text { Relation } \\
\text { soluble } \\
\text { solids/ } \\
\text { acidity }\end{array}$ & $-0.03^{n s}$ & $-0.02^{\mathrm{ns}}$ & $0.02^{\text {ns }}$ & $-0.22^{\mathrm{ns}}$ & $-0.15^{\mathrm{ns}}$ & $0.16^{\mathrm{ns}}$ & & & & \\
\hline & $h^{\circ}$ (Rind) & $-0.04^{\mathrm{ns}}$ & $-0.07^{n s}$ & $0.19^{n s}$ & $-0.78^{\star \star}$ & $-0.92^{\star \star}$ & & & & & \\
\hline & $C($ Rind $)$ & $0.02^{\text {ns }}$ & $0.06^{\mathrm{ns}}$ & $-0.18^{n s}$ & $0.77^{\star \star}$ & & & & & & \\
\hline & $L$ (Rind) & $0.15^{\mathrm{ns}}$ & $0.11^{\text {ns }}$ & $-0.14^{\mathrm{ns}}$ & & & & & & & \\
\hline & $h^{\circ}$ (Juice) & $-0.34^{\star \star}$ & $0.20^{\text {ns }}$ & & & & & & & & \\
\hline & C (Juice) & $0.42^{\star \star}$ & & & & & & & & & \\
\hline \multirow{10}{*}{$\begin{array}{l}\text { P. edulis/ } \\
\text { P.edulis }\end{array}$} & $\beta$-carotene & $-0.10^{\mathrm{ns}}$ & $-0.15^{\mathrm{ns}}$ & $-0.01^{\mathrm{ns}}$ & $0.16^{\mathrm{ns}}$ & $0.18^{\text {ns }}$ & $-0.18^{\mathrm{ns}}$ & $0.34^{*}$ & $0.22^{\text {ns }}$ & $-0.20^{\mathrm{ns}}$ & $-0.37^{\star}$ \\
\hline & $\begin{array}{l}\text { Ascorbic } \\
\text { acid }\end{array}$ & $0.03^{\text {ns }}$ & $0.21^{\mathrm{ns}}$ & $0.15^{\text {ns }}$ & $-0.50^{\star \star}$ & $-0.43^{\star \star}$ & $0.29^{n s}$ & $-0.11^{\mathrm{ns}}$ & $-0.27^{\mathrm{ns}}$ & $-0.14^{\mathrm{ns}}$ & \\
\hline & $\begin{array}{c}\text { Titratable } \\
\text { acidity }\end{array}$ & $0.29^{n s}$ & $0.32^{\star}$ & $0.12^{\text {ns }}$ & $0.13^{\text {ns }}$ & $0.09^{n s}$ & $-0.09^{n s}$ & $-0.71^{\star \star}$ & $0.14^{\mathrm{ns}}$ & & \\
\hline & $\begin{array}{l}\text { Soluble } \\
\text { solids }\end{array}$ & $-0.11^{\text {ns }}$ & $-0.18^{\mathrm{ns}}$ & $0.22^{\text {ns }}$ & $0.33^{\star}$ & $0.37^{\star}$ & $-0.30^{\star}$ & $0.59^{\star \star}$ & & & \\
\hline & $\begin{array}{l}\text { Relation } \\
\text { soluble } \\
\text { solids/ } \\
\text { acidity }\end{array}$ & $-0.32^{\star}$ & $-0.39^{\star \star}$ & $-0.14^{\mathrm{ns}}$ & $0.17^{\mathrm{ns}}$ & $0.22^{\text {ns }}$ & $-0.17^{\mathrm{ns}}$ & & & & \\
\hline & $h^{\circ}$ (Rind) & $0.44^{\star \star}$ & $0.30^{\star}$ & $0.21^{\text {ns }}$ & $-0.82^{\star \star}$ & $-0.82^{\star \star}$ & & & & & \\
\hline & $C($ Rind $)$ & $-0.33^{\star}$ & $-0.24^{\mathrm{ns}}$ & $-0.10^{\mathrm{ns}}$ & $0.91^{\star \star}$ & & & & & & \\
\hline & $L$ (Rind) & $-0.30^{\star}$ & $-0.19^{n s}$ & $-0.19^{n s}$ & & & & & & & \\
\hline & $h^{\circ}$ (Juice) & $0.24^{\mathrm{ns}}$ & $0.61^{\star \star}$ & & & & & & & & \\
\hline & $C$ (Juice) & $0.65^{\star \star}$ & & & & & & & & & \\
\hline
\end{tabular}


Table 2. Continuation...

\begin{tabular}{|c|c|c|c|c|c|c|c|c|c|c|c|}
\hline Species & Variables & $\begin{array}{c}L \\
\text { (Juice) }\end{array}$ & $\begin{array}{c}\text { C } \\
\text { (Juice) }\end{array}$ & $\begin{array}{c}h^{\circ} \\
\text { (Juice) }\end{array}$ & $\stackrel{L}{L}$ & $\underset{\text { (Rind) }}{C}$ & $\begin{array}{c}h^{\circ} \\
\text { (Rind) }\end{array}$ & $\begin{array}{c}\text { Relation } \\
\text { soluble } \\
\text { solids/acidity }\end{array}$ & $\begin{array}{c}\text { Soluble } \\
\text { solids }\end{array}$ & $\begin{array}{c}\text { Titratable } \\
\text { acidity }\end{array}$ & $\begin{array}{c}\text { Ascorbic } \\
\text { acid }\end{array}$ \\
\hline \multirow{10}{*}{$\begin{array}{c}\text { P.edulis } \\
\text { (non-grafted) }\end{array}$} & $\beta$-carotene & $0.33^{\text {ns }}$ & $0.23^{\text {ns }}$ & $-0.15^{\mathrm{ns}}$ & $0.14^{\mathrm{ns}}$ & $0.17^{n s}$ & $0.45^{\text {ns }}$ & $0.29^{\text {ns }}$ & $0.42^{\text {ns }}$ & $-0.09^{\text {ns }}$ & $0.57^{\text {ns }}$ \\
\hline & $\begin{array}{l}\text { Ascorbic } \\
\text { acid }\end{array}$ & $-0.07^{n s}$ & $-0.11^{\text {ns }}$ & $0.11^{\mathrm{ns}}$ & $-0.07^{n s}$ & $-0.06^{\mathrm{ns}}$ & $0.18^{\mathrm{ns}}$ & $0.68^{\star}$ & $0.05^{\text {ns }}$ & $-0.49^{\text {ns }}$ & \\
\hline & $\begin{array}{c}\text { Titratable } \\
\text { acidity }\end{array}$ & $0.62^{\text {ns }}$ & $0.65^{\star}$ & $-0.27^{\mathrm{ns}}$ & $0.03^{\text {ns }}$ & $-0.25^{\mathrm{ns}}$ & $0.25^{\mathrm{ns}}$ & $-0.91^{\star \star}$ & $0.68^{*}$ & & \\
\hline & $\begin{array}{c}\text { Soluble } \\
\text { solids }\end{array}$ & $0.65^{\star}$ & $0.58^{\text {ns }}$ & $-0.39^{\text {ns }}$ & $-0.31^{\mathrm{ns}}$ & $-0.13^{\text {ns }}$ & $0.83^{\star \star}$ & $-0.36^{\mathrm{ns}}$ & & & \\
\hline & $\begin{array}{l}\text { Relation } \\
\text { soluble } \\
\text { solids/ } \\
\text { acidity }\end{array}$ & $-0.50^{\text {ns }}$ & $-0.57^{\mathrm{ns}}$ & $0.24^{\mathrm{ns}}$ & $-0.28^{n s}$ & $0.08^{\text {ns }}$ & $0.12^{\mathrm{ns}}$ & & & & \\
\hline & $h^{\circ}$ (Rind) & $0.36^{\mathrm{ns}}$ & $0.24^{\mathrm{ns}}$ & $-0.27^{\text {ns }}$ & $-0.62^{\text {ns }}$ & $-0.10^{\text {ns }}$ & & & & & \\
\hline & $C$ (Rind) & $0.01^{\mathrm{ns}}$ & $0.01^{\mathrm{ns}}$ & $-0.23^{\text {ns }}$ & $0.34^{\mathrm{ns}}$ & & & & & & \\
\hline & $L$ (Rind) & $-0.21^{\mathrm{ns}}$ & $0.56^{\mathrm{ns}}$ & $0.10^{\text {ns }}$ & & & & & & & \\
\hline & $h^{\circ}$ (Juice) & $-0.65^{\star}$ & $-0.65^{\star}$ & & & & & & & & \\
\hline & C (Juice) & $0.99^{\star \star}$ & & & & & & & & & \\
\hline
\end{tabular}

${ }^{\star} \mathrm{p}<0.05$; ${ }^{* \star} \mathrm{p}<0.01 ;{ }^{\text {"s }}$ not significant at $\mathrm{p}<0.05$.

With the combination P. edulis / P. edulis (autograft), the content of $\beta$-carotene was significantly correlated with the contents of ascorbic acid (29.64 g per $100 \mathrm{~g}$ of citric acid) and, in turn, the content of ascorbic acid was highly correlated with luminosity values and the chroma of the rind of the fruit with values of 71.29 and 38.88, respectively, indicating that the rind of the fruit has high saturation of pigments. Several authors have reported positive correlations between ascorbic acid and antioxidant activity (ContrerasCalderón et al. 2010; Rufino et al. 2010), while others have found no correlation (Almeida et al. 2011).

Finally, the combination P. edulis (ungrafted) obtained no significant correlation with the content of $\beta$-carotene and ascorbic acid. Perhaps this phenomenon is due to uneven ripening and harvest of the fruits because of the early flowering of grafted plants and the late flowering of non-grafted ones, as reported by Salazar et al. (2015). In the current research, harvest was carried out for five months beginning 190 days after transplantation.

Our results conform with those of Giorgi et al. (2005), who compared the effects induced by five of the most common rootstocks on peach (cv. 'Suncrest') plant development and yield, as well as on fruit quality, across two seasons of full production. These authors observed that, while firmness, soluble solids, and the ratio between total soluble solids and acidity in the fruits were affected only slightly by the different rootstocks, the total acidity of the fruit varied significantly according to the rootstock. Likewise, Drogoudi and Tsipouridis (2007) determined the variability in the antioxidant content and physical characters in fruit from nine clingstone peach cultivars/genotypes (Prunus persica L. Batsch) grafted on three rootstocks. These authors concluded that, while the effects of rootstock on the fruit antioxidant contents were not pronounced, a pronounced cultivar effect on the fruit antioxidant content was found. The relative low effect observed for rootstocks on the peach antioxidant content may be attributed to the close genetic origin of the studied rootstocks; nevertheless, effects on fruit weight were documented. Daza et al. (2008) analyzed the influence of eight different rootstocks on several fruit quality parameters of 'Pioneer' Japanese plum. These authors found that the effect of the different rootstocks on most of the analysed quality parameters was variable because of a strong interaction rootstock versus year. However, several parameters, such as fruit shape, soluble solid concentration, acidity and maturity, did not show significant differences year-by-year. On the other hand, Bassal (2009) evaluated the vegetative growth, yield and fruit quality of 'Marisol' clementine, as a newly introduced cultivar in Egypt, budded on four commercial rootstocks (Sour orange, Cleopatra mandarin, Carrizo citrange and 'Swingle' citrumelo). The results of 
this investigation showed that the tree size, yield, and fruit quality of 'Marisol' clementine can be controlled by the proper selection of rootstock. Rato et al. (2008) compared the effects induced by two different plum rootstocks (GF8-1 and GF10-2) and two different soils (Haplic Luvisol and Vertic Luvisol) on growth, fruit yield, mineral composition and fruit quality of plums. At harvest, soluble solids content and soluble solids content/ titratable acidity ratio were not affected by soil type or rootstock.

In our research, of all the grafting combinations tested, passionfruit juice grafted in wild species of the genus Passiflora had a content of $\beta$-carotene, ascorbic acid ( $\geq 20 \mathrm{mg}$ ascorbic acid per $100 \mathrm{~g}$ of juice) and fruit quality similar to those that were not grafted. Therefore, these fruits can have a nutritional and economic value equal to that of non-grafted plants.

\section{CONCLUSION}

The content of $\beta$-carotene in the fruit showed no statistical differences among the grafting treatments, indicating no significant rootstock effect on the evaluated fruit quality variables. The results thus indicate the potential of wild rootstock use for its positive effects, without affecting the commercial quality of the fruits of passionfruit crops.

\section{ACKNOWLEDGEMENTS}

We acknowledge the National Council for Scientific and Technological Development (CNPq), the Coordination for the Improvement of Higher Education Personnel (CAPES) and the Minas Gerais Research Foundation (FAPEMIG) for their financial support.

\section{REFERENCES}

Almeida, M. M. B., Souza, P. H. M., Arriaga, A. M. C., Prado, G. M. P., Magalhães, C. E. C. and Mais, G. A. M. (2011). Bioactive compounds and antioxidant activity of fresh exotic fruits from northeastern Brazil. Food Research International, 44, 2155-2159. http://dx.doi.org/10.1016/j.foodres.2011.03.051.

Atucha, A., Emmet, B. and Bauerle, T. L. (2014). Growth rate of fine root systems influences rootstock tolerance to replant disease. Plant and Soil, 376, 337-346. http://dx.doi.org/10.1007/ s11104-013-1977-5.

Babbar, N., Oberoi, H. S., Uppal, D. S. and Patil, R. T. (2011). Total phenolic content and antioxidant capacity of extracts obtained from six important fruit residues. Food Research International, 44, 391-396. http://dx.doi.org/10.1016/j.foodres.2010.10.001.

Bassal, M. A. (2009). Growth, yield and fruit quality of 'Marisol' clementine grown on four rootstocks in Egypt. Scientia Horticulturae, 119, 132-137. http://dx.doi.org/10.1016/ j.scienta.2008.07.020.

Campos, F. M., Pinheiro-Sant’ana, H. M., Souza, P. M., Stringheta, P. C. and Chaves, J. B. P. (2006). Pró-vitaminas A em hortaliças comercializadas no mercado formal e informal de Viçosa (MG), em três estações do ano. Ciência e Tecnologia de Alimentos, 26, 33-40. http://dx.doi.org/10.1590/S0101-20612006000100006.
Cavichioli, J. C., Correa, L. S., Garcia, M. J. M. and Fischer, I. H. (2011). Desenvolvimento, produtividade e sobrevivência de maracujazeiro amarelo enxertado e cultivado em área com histórico de morte prematura de plantas. Revista Brasileira de Fruticultura, 33, 567-574. http://dx.doi.org/10.1590/S0100-29452011005000075.

Coelho, A. A., Cenci, S. A. and Resende, E. D. (2010). Qualidade do suco de maracujá-amarelo em diferentes pontos de colheita e após o amadurecimento. Ciência e Agrotecnologia, 34, 722-729. http://dx.doi.org/10.1590/S1413-70542010000300027.

Contreras-Calderón, J. C., Jaimes, L. C., Hernández, E. G. and Villanova, B. G. (2010). Antioxidant capacity, phenolic content and vitamin $C$ in pulp, rind and seed from 24 exotic fruits from Colombia. Food Research International, 44, 2047-2053. http://dx.doi.org/10.1016./j.foodres.2010.11.003.

Daza, A., Garcia-Galavis, P. A., Grande, M. J. and Santamaria, C. (2008). Fruit quality parameters of 'Pioneer' Japanese plums produced on eight different rootstocks. Scientia Horticulturae, 118, 206-211. http://dx.doi.org/10.1016/j.scienta.2008.06.003.

Drogoudi, P. D. and Tsipouridis, C. G. (2007). Effects of cultivar and rootstock on the antioxidant content and physical characters of clingstone peaches. Scientia Horticulturae, 115, 34-39. http://dx.doi.org/10.1016/j.scienta.2007.07.009. 
Giorgi, M., Capocasa, F., Scalzo, J., Murri, G., Battino, M. and Mezzetti, B. (2005). The rootstock effects on plant adaptability, production, fruit quality, and nutrition in the peach (cv. 'Suncrest'). Scientia Horticulturae, 107, 36-42. http://dx.doi.org/10.1016/j. scienta.2005.06.003.

Ingale, S. P. and Kasture, S. B. (2014). Antioxidant and antiparkinsonian activity of Passiflora incarnata leaves. Oriental Pharmacy and Experimental Medicine, 14, 231-236. http://dx.doi.org/10.1007/ s13596-014-0149-3.

Lee, S. K. and Kader, A. A. (2000). Preharvest and postharvest factors influencing vitamin $\mathrm{C}$ content of horticultural crops. Postharvest Biology and Technology, 20, 207-220. http://dx.doi.org/10.1016/ S0925-5214(00)00133-2.

Lichtenthaler, H. K. (1987). Chlorophylls and carotenoids: pigments of photosynthetic biomembranes. Methods in Enzymology, 148, 350-382. http://dx.doi.org/10.1016/0076-6879(87)48036-1.

Machado, B. D., Rufato, L., Bogo, A., Kretzchmarl, A. A. and Mario, A. E. (2013). Cultivares e portaenxertos sobre o vigor de plantas de pereira europeias. Ciência Rural, 43, 1542-1545. http://dx.doi. org/10.1590/S0103-84782013005000105.

Matarazzo, P. H. M., Siqueira, D. L., Salomão, L. C. C., Silva, D. F. P. and Cecon, P. R. (2013). Desenvolvimento dos frutos de lulo (Solanum quitoense Lam), em Viçosa-MG. Revista Brasileira de Fruticultura, 35,131-142. http://dx.doi.org/10.1590/S0100-29452013000100016.

Meletti, L. M. M. (2011). Avanços na cultura do maracujá no Brasil. Revista Brasileira de Fruticultura, 33, 83-91. http://dx.doi.org/10.1590/ s0100-29452011000500012.

Ocampo, J., Coppens d'Eeckenbrugge, G., Restrepo, M., Jarvis, A., Salazar, M. and Caetano, C. (2007). Diversity of Colombian Passifloraceae: biogeography and an updated list for conservation. Biota Colombiana, 8, 1-45.

Ocampo, J., Urrea, R., Wyckhuys, W. and Salazar, M. (2013). Exploración de la variabilidad genética del maracuyá (Passiflora edulis f. flavicarpa Degener) como base para un programa de fitomejoramiento en Colombia. Acta Agronómica, 62, 352-360.

Pabón, L. M., Turbay, S., Rojano, B., Álvarez, L. M., Restrepo, S. L., Álvarez, J. M., Bonilla, K. C., Ochoa, C. and Sánchez, N. (2011). Algunas especies de Passiflora y su capacidad antioxidante. Revista Cubana de Plantas Medicinales, 16, 354-363.

Pérez-Jiménez, J., Arranz, S., Tabernero, M., Díaz-Rubio, M. E., Serrano, J., Goñi, I. and Saura-Calixto, F. (2008). Updated methodology to determine antioxidant capacity in plant foods, oils and beverages: extraction, measurement and expression of results. Food Research International, 41, 274-285. http://dx.doi. org/10.1016/j.foodres.2007.12.004.

Ramful, D., Bahorun, T., Bourdon, E., Tarnus, E. and Aruoma, O. I. (2010). Bioactive phenolics and antioxidant propensity of flavedo extracts of Mauritian citrus fruits: potential prophylactic ingredients for functional foods application. Toxicology, 278, 75-87. http://dx.doi. org/10.1016/j.tox.2010.01.012.

Ramful, D., Tarnus, E., Aruoma, O. I., Bourdan, E. and Bahorun, T. (2011). Polyphenol composition, vitamin C content and antioxidant capacity of Mauritian citrus fruit pulps. Food Research International, 44, 2088-2099. http://dx.doi.org/10.1016/j.foodres.2011.03.056.

Rato, A. E., Agulheiro, A. C., Barroso, J. M. and Riquelme, F. (2008). Soil and rootstock influence on fruit quality of plums (Prunus domestica L.). Scientia Horticulturae, 118, 218-222. http://dx.doi. org/10.1016/j.scienta.2008.06.013.

Rotili, M. C. C, Coutro, S., Celant, V. M., Vorpagel, J. A., Barp, F. K., Salibe, A. B. and Braga, G. C. (2013). Composição, atividade antioxidante e qualidade do maracujá-amarelo durante armazenamento. Semina: Ciências Agrárias, 34, 227-240. http:// dx.doi.org/10.5433/1679-0359.2013v34n1p227.

Rufino, M. S. M., Alves, R. E., Brito, E. S., Jiménez, J. P., Calixto, F. S. and Mancini Filho, J. (2010). Bioactive compounds and antioxidant capacities of 18 non-traditional tropical fruits from Brazil. Food Chemistry, 121, 996-1022. http://dx.doi.org/10.1016/j.foodchem.2010.01.037.

Salazar, A. H., Silva, D. F. P., Sediyama, C. S. and Bruckner, C. H. (2015). Caracterização física e química de frutos de maracujazeiroamarelo enxertado em espécies silvestres do gênero passiflora cultivado em ambiente protegido. Revista Brasileira de Fruticultura, 37, 630-638. http://dx.doi.org/10.1590/0100-2945-101/14.

Santos, C. E. M., Bruckner, C. H., Cruz, C. D., Siqueira, D. L. and Pimentel, L. D. (2009). Características físicas do maracujá-azedo em função do genótipo e massa do fruto. Revista Brasileira de Fruticultura, 31, 1102-1110. http://dx.doi.org/10.1590/S0100-29452009000400025.

SAS Institute (2002). EEUU. Version 9.0. Cary: SAS Institute.

Silva, A., Oliveira, E. J., Haddad, F., Laranjeira, F., Jesus, O., Oliveira, S. A., Carvalho, M. A. and Freitas, P. X. (2013). Identification of passion fruit genotypes resistant to Fusarium oxysporum f. sp. Passiflorae. Tropical Plant Pathology, 38, 236-242. http://dx.doi. org/10.1590/S1982-56762013005000008. 
Silva, D. F. P, Matias, R. G. P., Silva, J. O. C., Cremasco, J. P. G., Salazar, A. H. and Bruckner, C. H. (2014). Alterações nos níveis de antioxidantes em polpa de manga. Revista Brasileira de Agropecuária Sustentável, 4, 26-31.

Souza, V. R., Pereira, P. A. P., Queiroz, F., Borges, S. V. and Carneiro, J. D. S. (2012). Determination of bioactive compounds, antioxidant activity and chemical composition of Cerrado Brazilian fruits. Food Chemistry, 134, 381-386. http://dx.doi.org/10.1016/j.foodchem.2012.02.191.

Stevens, R., Page, D., Gouble, B., Garchery, C., Zamir, D. and Causse, M. (2008). Tomato fruit ascorbic acid content is linked with monodehydroascorbate reductase activity and tolerance to chilling stress. Plant Cell and Environment, 31, 1086-1096. http://dx.doi.org/10.1111/j.1365-3040.2008.01824.x.
Uenojo, M., Maróstica Junior, M. R., Pastore, G. M. (2007). Carotenóides: propriedades, aplicações e biotransformação para formação de compostos de aroma. Química Nova, 30, 616-622. http://dx.doi.org/10.1590/S0100-40422007000300022.

Wang, S., Melnyk, J. P., Tsao, R. and Marcone, M. F. (2011). How natural dietary antioxidants in fruits, vegetables and legumes promote vascular health. Food Research International, 44, 14-22. http://dx.doi.org/10.1016/j.foodres.2010.09.028.

Wong, Y. S., Sia, C. M., Khoo, H. E., Ang, Y. K., Chang, S. K. and Yim, H. S. (2014). Influence of extraction conditions on antioxidant properties of passion fruit (Passiflora edulis) peel. Acta Scientiarum Polonorum. Technologia Alimentaria, 13, 257-265. 